\title{
Políticos de Deus: análise das campanhas de evangélicos eleitos para Deputado Federal por São Paulo (2010, 2014 e 2018)
}

\author{
Politicians of God: an analysis of the political campaigns of \\ evangelicals elected for São Paulo to the House of Representatives \\ (2010, 2014, 2018)
}

\section{Mércia Alves \\ Priscilla Leine Cassotta}

\section{Resumo}

O artigo discute a inserção de evangélicos na política partidária e eleitoral, problematizando a utilização que esses candidatos fazem dos meios de comunicação em suas campanhas. Busca-se identificar as principais estratégias utilizadas por esses candidatos para que sejam reconhecidos pela audiência como uma liderança cristã. Foram analisados os programas veiculados pelo Horário Gratuito de Propaganda Eleitoral dos candidatos evangélicos eleitos para Deputados Federais por São Paulo nas eleiçóes de 2010, 2014 e 2018 a partir dos conceitos de formação ideológica e interdiscursividade, tal como abordados pelos autores da análise do discurso. Os principais resultados encontrados foram uma oferta eleitoral comum, suprapartidária e independente de denominação religiosa, baseada na preservação de valores tradicionais e no combate a um inimigo comum, que representa a diluição desses valores.

\section{Palavras-chave}

Eleiçóes Legislativas; Campanhas Eleitorais; Candidatos Evangélicos.

\begin{abstract}
The article discusses the insertion of evangelicals in party and electoral politics, questioning the use that these candidates make of the media in their campaigns. Thus, we seek to identify the main strategies used by these candidates so that they are recognized by the audience as a Christian leadership. The programs of the evangelical candidates elected to the position of Federal Deputy by the State of São Paulo in the 2010, 2014 and 2018 elections that were broadcasted by the free broadcasting time for electoral campaigns were analyzed. The main results found were a common electoral offer, non-partisan and independent of religious denomination, based on the preservation of traditional values and the fight against a common enemy, which represents the dilution of these values.
\end{abstract}

\section{Keywords}

Legislative Elections; Electoral Campaigns; Evangelical Candidates. 


\section{Introdução}

$\mathrm{O}$ artigo discute a inserção de evangélicos na política partidária e eleitoral, problematizando a utilização que esses candidatos fazem dos meios de comunicação em suas campanhas. Busca-se identificar nos discursos desses candidatos religiosos as principais estratégias utilizadas para que sejam reconhecidos pela audiência como uma liderança cristã. Para tanto, serão analisados os programas veiculados pelo Horário Gratuito de Propaganda Eleitoral - HGPE dos candidatos eleitos para o cargo de Deputado Federal pelo Estado de São Paulo nas eleições de 2010, 2014 e 2018 que compóem a bancada evangélica.

$\mathrm{O}$ artigo está fundamentado em duas premissas: a primeira - tratada na seção seguinte - diz respeito à importância do crescimento desse grupo religioso na política. A chamada "Bancada Evangélica" na Câmara dos Deputados tem apresentado crescimento significativo nas últimas eleiçôes (CASSOTTA, 2019). A Frente Parlamentar Evangélica é composta por políticos autodeclarados evangélicos de diversas denominações, distribuídos em diferentes partidos políticos. Essa frente se articula de forma conservadora em torno de temas específicos, relacionados a diretos humanos, principalmente as questões de gênero, aborto, diversidade sexual e direitos de Lésbicas, Gays, Bissexuais, Travestis, Transexuais ou Transgêneros - LGBTs, assim como políticas de saúde pública e educação relacionadas a esses temas.

A segunda premissa, abordada na terceira seção, é a importância da televisão como meio de informação durante os processos eleitorais. Os estudos sobre HGPE (PANKE e MACEDO, 2013) representam um nicho bastante consolidado no campo da comunicação política, principalmente para campanhas majoritárias para os poderes executivos. Desde o final da década de 1980 e meados da década seguinte até hoje, tem-se as campanhas da TV marcando o "tempo da política" (ALDÉ, 2011), em outras palavras, influenciando a percepção do eleitorado e a agenda dos demais meios de comunicação (AZEVEDO, 2018).

O presente artigo relaciona duas linhas de pesquisas da Ciência Política: 1) campanhas eleitorais para o Legislativo; 2) campanhas de candidatos evangélicos. Questiona-se: de que forma a condição de religioso é construída nos discursos políticos-eleitorais? A hipótese é que a condição religiosa está expressa nos discursos desses candidatos como forma de reconhecimento, identificação e autoridade, vinculando as suas imagens à representação de valores tradicionais no campo políticolegislativo. Em outras palavras, a imagem veiculada corresponde a critérios religiosos, e a campanha na TV é meio de consolidação do capital social de que dispõem. 
As campanhas eleitorais dos candidatos evangélicos eleitos por São Paulo nos pleitos de 2010, 2014 e 2018 serão analisadas a partir dos conceitos de formação ideológica e interdiscursividade, tal como abordados pelos autores da análise discursiva (ORLANDI, 2012; GREIMAS, 1975; MAGALHÃES e MARIANI, 2010; CHARAUDEAU e MAINGUENEAU, 2004). A partir disso, as conclusões apontam que os sentidos mobilizados nas campanhas dos candidatos são, em resumo, dois: a oferta eleitoral comum, independentemente de partido pelo qual se candidata e da denominação religiosa, baseada na preservação de valores tradicionais; e o inimigo comum a ser combatido, que representa a diluição da família, da moral cristá, e que é um risco à vida. Esse inimigo é representado pela esquerda, novamente, no sentido amplo do conceito (BOBBIO, 1994).

\section{Politicas partidárias e pentecostais: os politicos de Deus}

$\mathrm{O}$ vínculo entre política e religião no Brasil tem sido, especialmente em anos eleitorais, cada vez mais debatido e estudado por cientistas políticos (CASSOTTA, 2016; CERQUEIRA, 2017; LACERDA, 2017). Deveras, a cada eleição, representantes evangélicos têm progressivamente conquistado mais cadeiras no Congresso Nacional e postos como chefe do Executivo nas 3 esferas da federação.

A presença dos evangélicos na política brasileira é acompanhada pelo crescimento demográfico desses cristãos e da redemocratização do país (ALMEIDA, 2014). Esse segmento religioso no Brasil, a partir do ano de 2010, já contava com pouco mais de $22 \%$ de uma população de 190 milhóes de habitantes. Esse crescimento é acompanhado do declínio da religião católica.

Tabela 1 - Distribuição percentual da população residente, segundo os grupos de religião -2000/2010

\begin{tabular}{l|l|l}
\hline & $\mathbf{2 0 0 0}$ & $\mathbf{2 0 1 0}$ \\
\hline Católica Apostólica Romana & 73,6 & 64,6 \\
\hline Evangélicos & 15,4 & 22,2 \\
\hline Espírita & 1,3 & 2 \\
\hline Umbanda e Candomblé & 0,3 & 0,3 \\
\hline Sem religiáo & 7,4 & 8 \\
\hline Outras religiosidades & 1,8 & 2,7 \\
\hline Não sabe/ Náo declarou & 0,2 & 0,1 \\
\hline Fen
\end{tabular}

Fonte: Adaptado de IBGE (2010).

Nota-se ainda que, embora os indivíduos sem religião também tenham crescido, o aumento dos adeptos do cristianismo evangélico é bem expressivo. No 
entanto, segundo Santos (2013), explorar a condição de religioso desses políticos como principal recurso eleitoral não é garantia de voto. Ainda assim, é razoável assumir que a religião possa exercer influência entre os seus membros no que diz respeito às suas escolhas políticas, por razões como senso de comunidade, identidade e a relação de confiança gerada pelos líderes religiosos (CERQUEIRA, 2017). Nessa direção, o campo político institucional não se mostrou insensível à interpelação evangélica, de forma que os canais de relacionamento entre lideranças políticas (em ambas as esferas) foram alargados nos últimos anos (ORO, 2011). Procuradas por diversos partidos, as Igrejas Evangélicas passaram a desempenhar papel importante não apenas nas eleições proporcionais, mas também nas majoritárias.

Foi na Constituinte, em 1986, que os evangélicos ganharam, pela primeira vez, papel mais significativo em termos de cargos públicos conquistados. Somada aos protestantes históricos, a chamada "bancada evangélica" na Constituinte passou a contar com 33 deputados, que passam a compor uma nova opção para o voto conservador no país (PIERUCCI e PRANDI, 1996).

Nas eleiçóes de 1989, Edir Macedo, líder da Igreja Universal do Reino de Deus, chegou a afirmar que: "Após orar e pedir a Deus que indicasse uma pessoa, o Espírito Santo nos convenceu de que Fernando Collor de Mello era o escolhido"1 (apud MARIANO e PIERUCCI, 1992, p. 94). O candidato do PT, Lula da Silva, de acordo com essas lideranças religiosas, colocaria em risco os valores morais da família tradicional, além de ser associado com o comunismo. No pleito seguinte, em 1994, os evangélicos continuam a pregação contrária ao candidato do PT, Lula, que chegou a ser associado como um "demônio" (MARIANO, 2005).

Nas eleições de 1998, o maior protagonismo dos evangélicos foi para os cargos do Executivo estadual e Legislativo. Cabe destacar o Rio de Janeiro, estado brasileiro que apresenta um dos maiores percentuais de cristãos evangélicos e que elegeu Anthony Garotinho para o cargo de governador pelo Partido Democrático Trabalhista (PDT), tendo como vice-governadora Benedita da Silva pelo PT, ambos evangélicos declarados (MACHADO, 2006).

Interessante destacar que, embora Lula - PT tenha sido taxado como uma ameaça aos evangélicos durante as primeiras eleições presidenciais pós-abertura política, foi ele quem ampliou as alianças políticas com esse segmento no pleito de 2002. Com a derrota do evangélicos Anthony Garotinho - PSB no primeiro turno, o

${ }^{1}$ Jornal do Brasil, 3 de dezembro de 1989. 
apoio dos cristãos passou a ser dado ao candidato do PT. Esse apoio partiu principalmente da Igreja Universal do Reino de Deus (GONÇALVES, 2011) e se estendeu durantes os pleitos seguintes.

$\mathrm{Na}$ campanha eleitoral de 2006, Lula e o PT tiveram como prioridade de agenda a conquista do voto evangélico (ORO, 2011). Para tanto, lograram obter apoio de diferentes lideranças religiosas das principais igrejas evangélicas. $\mathrm{O}$ candidato do PT participou de reunióes com lideranças evangélicas, prometeu ampliar as parcerias na área social entre o governo federal e as igrejas desse segmento, pediu votos e contou com um comitê destinado a esses religiosos (MARIANO, HOFF e DANTAS, 2006). Entre os evangélicos influentes, em 2006 Lula conseguiu apoio de Marcelo Crivella ${ }^{2}$, que lhe garantiu o suporte oficial das igrejas Assembleia de Deus e Igreja Universal do Reino de Deus (IURD). Como contrapartida, Lula e o PT apoiaram Crivella em sua candidatura ao governo do Estado do Rio de Janeiro, oficializando a coligação em março de 2006 (MARIANO, HOFF e DANTAS, 2006).

Nas eleições de 2010, Marina Silva, candidata pelo Partido Verde - PV, era a única dos presidenciáveis identificada diretamente com os evangélicos. Por conta disso, sofreu dentro do próprio partido, pois, logo após oficializar a sua candidatura, um grupo de políticos do PV acusou o próprio partido de abandonar sua luta pela legalização do aborto e união homoafetiva (ORO e MARIANO, 2011). Por sua vez, a candidata Dilma Rousseff pelo PT, sofreu com forte campanha difamatória por demonstrar simpatia por questões como a união homoafetiva (TADVALD, 2010). A fim de reverter esse quadro, Dilma, junto a Lula, chegou a se reunir com mais de 60 lideranças religiosas reafirmando o seu compromisso com o povo evangélico de que não enviaria proposta ao Congresso Nacional sobre a legalização do aborto (TADVALD, 2010).

$\mathrm{Na}$ arena legislativa, no ano de 2003, foi criada a Frente Parlamentar Evangélica. Em menos de 20 anos, os evangélicos duplicaram a sua base parlamentar, reforçando a chamada "bancada evangélica".

\footnotetext{
${ }^{2}$ Em um evento evangélico arranjado por Crivela, Lula se encontrou com diversos cantores gospel e discursou: "Quis Deus que fosse esse, que era chamado de demônio, que fosse lá sancionar o Código Civil que permite total liberdade de religião neste país” (cf MARIANO, HOFF e DANTAS, 2006, p. 66).
} 
Gráfico 1 - Número de Deputados Evangélicos na Câmara ${ }^{3}$

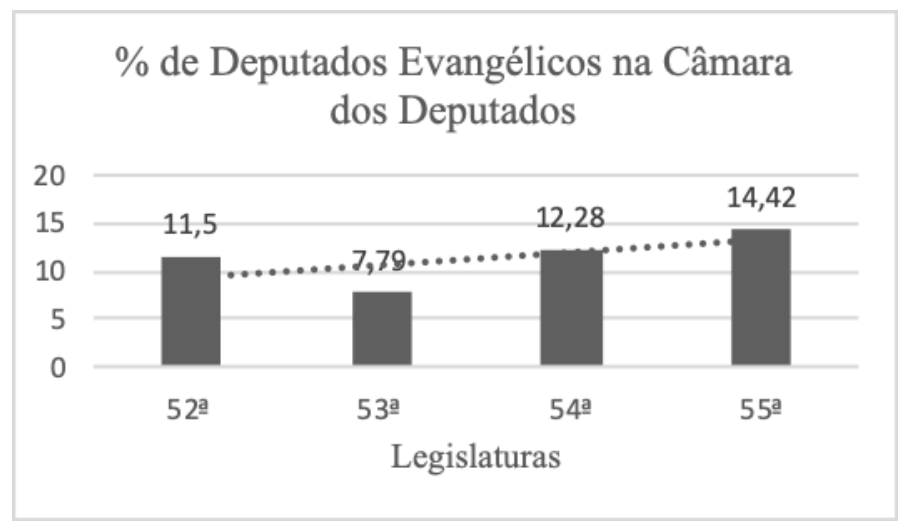

Fonte: Adaptado de Oro (2006) e DIAP (2018).

A perda de cadeiras da bancada evangélica sofrida no ano de 2007 - na $53^{a}$ legislatura - é o resultado do envolvimento desses políticos no escândalo da Máfia dos Sanguessugas ${ }^{4}$, que diz respeito ao esquema de corrupção de superfaturamento na venda de ambulâncias para diversas prefeituras em troca de emendas parlamentares, as quais tiveram protagonismo maciço de parlamentares evangélicos (SOUZA, 2009). Para tentar diminuir os danos, as grandes denominações pentecostais, como a Universal e a Assembleia de Deus, retiraram o apoio político aos deputados envolvidos, fator que pode ser associado à redução da bancada na legislatura seguinte (MARIANO, HOFF e DANTAS, 2006). Entretanto, com exceção dessa legislatura, é perceptível o crescimento do número de deputados ligados a essa vertente religiosa.

Apesar de na $54^{\mathrm{a}}$ Legislatura os deputados evangélicos ainda estarem espalhados em diferentes partidos políticos ${ }^{5}$, representando diferentes estados do Brasil, o PSC e PRB se destacaram pelo número de políticos dessa vertente religiosa.

\footnotetext{
${ }^{3}$ Porcentagem com relação aos 513 deputados que compóem a Câmara.

${ }^{4}$ Segundo depoimentos colhidos pela Justiça Federal e CPMI, acredita-se que a bancada evangélica participou ativamente do esquema, arrecadando uma média de $\mathrm{R} \$ 53$ milhóes (cf MARIANO, HOFF e DANTAS, 2006).

5 Partido Progressista, Partido do Movimento Democrático Brasileiro, Partido da Social Democracia Brasileira, Partido Social Cristão, Democratas, Partido dos Trabalhadores, Partido Republicano Brasileiro, Partido da República, Partido Trabalhista Cristão, Partido Verde, Partido Socialista Brasileiro, Partido Trabalhista Brasileiro, Partido Democrático Trabalhista e Partido da Mobilização Nacional.
} 
O PSC ganhou destaque pela atuação política de alguns dos seus deputados, com especial atenção ao Pastor Feliciano - líder da igreja Tempo de Avivamento, denominação ligada à Assembleia de Deus -, que foi nomeado para a presidência da Comissão de Direitos Humanos. Durante sua atuação como presidente da Comissão, Feliciano se empenhou numa pauta "antigay" e criou a subcomissão "Direito das Forças Armadas”, que foi presidida por Jair Bolsonaro, naquela época ainda deputado pelo PP/RJ. Além disso, criou polêmica em suas redes sociais como Twitter e blogs ao atacar a comunidade LGBT e ser favorável à censura e à redução da maioridade penal. Muitos evangélicos foram contra as declaraçôes do Marco Feliciano, colocando em dúvida a existência de um grupo religioso coeso.

Com a $55^{\text {a }}$ Legislatura, a bancada evangélica chega à sua maior expressão numérica. Na votação do impeachment da presidenta Dilma Roussef, se grande parte dos 513 deputados justificaram a destituição da presidenta como um ato "por Deus", poucos dias antes, no dia 06 de abril de 2016, a Frente Parlamentar Evangélica, por meio do seu presidente João Campos, declarou apoio à destituição da presidenta. Segundo o deputado declarou em nota, a decisão foi tomada pela "[...] grave crise econômica, moral, ética e política que atravessa o país" e pelos "recentes escândalos de corrupção praticados pelo governo e crimes de responsabilidade praticados por Dilma que constituem uma afronta ao povo e ao estado democrático de direito" (BRAGA e VENTURA, 2016)

Embora os governos de Lula e Dilma tenham estreitado relações com os evangélicos, Michel Temer - PMDB, após tomar posse como Presidente da República, em sua reforma ministerial, deu papel de destaque a esses religiosos. Para o Ministério do Desenvolvimento, Indústria e Comércio Exterior nomeou o Bispo Marcos Pereira, grande aliado de Edir Macedo. Para o Ministério do Trabalho nomeou o Pastor Ronaldo Nogueira. Para a Secretaria de Políticas para Mulheres, que objetiva implementar políticas para as mulheres, nomeou a deputada evangélica Fátima Pelaes, que já se declarou contra o aborto mesmo em caso de estupro (MORAES, 2016).

Nas eleições de 2018, questóes morais de cunho religioso, alinhadas com um forte conservadorismo nos costumes, estiveram na pauta de muitos candidatos ao Legislativo e Executivo. Jair Bolsonaro - PSL, mais que qualquer outro candidato, explorou essas questóes e conseguiu se aproximar do segmento evangélico ao se colocar como o paladino da defesa dos bons costumes e da família tradicional brasileira que expurgaria de nossa sociedade um marxismo cultural voltado à proteção de minorias. A relação entre Bolsonaro e os evangélicos se delineou de forma mais 
clara a partir de sua composição ministerial, com as indicaçôes dos evangélicos Onyx Lorenzoni (Igreja Luterana) como Ministro da Casa Civil e Damares Alves (pastora da Igreja Batista) como Ministra da Mulher, Família e Direitos Humanos.

\section{TV, campanhas e os politicos de Deus}

O HGPE é um dos principais recursos em uma campanha política. Para os eleitores, é uma fonte de informação política e eleitoral e, para os partidos, um meio de dar visibilidade pública às suas candidaturas e programas. Se os custos de informação para o eleitor são baixos, o mesmo não se pode dizer para o Estado, que compra o espaço de propaganda das emissoras geradoras UHF-VHF de rádio e TV; e para os partidos, que, além dos custos de produção dos programas, fazem destes uma importante moeda para o estabelecimento de coligaçóes eleitorais.

Ainda que sofra constantes alteraçóes, a legislação que regulamenta a propaganda eleitoral no Brasil mantém as suas características fundamentais desde a Lei 9. 504/1997 (BRASIL, 1997), como a garantia de espaço às coligaçôes formadas por partidos políticos com registro junto ao TSE, segundo o número de representantes eleitos para a Câmara dos Deputados no pleito anterior; exibição em dois períodos, mais inserçóes. Foi apenas com a Lei 13.165/2015 (BRASIL, 2015), conhecida como Minirreforma eleitoral, que pontos substanciais sofreram mudanças.

Entre as principais está a mudança no perfil de financiamento dessas campanhas, de misto - combina doaçóes individuais, de pessoas jurídicas e dos diretórios partidários - à proibição de recursos de pessoas jurídicas; o estabelecimento de tetos de recursos, contratação de serviços e de pessoal segundo o colégio eleitoral; a diminuição do tempo de campanha total, dos dias de campanha eleitoral no rádio e na TV e do tempo destinado diariamente no rádio e na TV para a propaganda (ALVES e LIMA, 2018). Entre as principais justificativas está a diminuição do custo das campanhas e, no caso da revisão do tempo de TV, a resolução da disparidade de tempo entre candidatos em eleiçóes gerais e intermediárias (ALVES, 2017).

A propaganda eleitoral veiculada pelos meios de comunicação de massa é central para as estratégias de comunicação das campanhas e para a construção da imagem dos candidatos (MANIN, 1995, 2013; AZEVEDO, 2004; GOMES, 1999; WEBER, 2004). É principalmente pela TV que o processo de modernização das campanhas se deu de forma contínua nas democracias representativas ocidentais (FARRELL, 2009; LISI, 2011). No entanto, com a multiplicação dos meios disponíveis para campanhas eleitorais, os candidatos dependem cada vez menos da 
TV e podem estabelecer outros canais de diálogo com o eleitor, mais dinâmicos e sem o intermédio da linguagem pré-estabelecida.

As últimas eleições realizadas no Brasil, principalmente para os cargos executivos municipal, estadual e federal, mostram que os candidatos dependem menos, ou não exclusivamente, da TV para obter êxito (BRAGA e CARLOMAGNO, 2018). Para os candidatos à Câmara dos Deputados, a multiplicidade de canais de informação não é novidade, porque são mais numerosos e dividem um espaço mais restrito na TV e, em maioria, fazem campanhas mais centralizadas.

No caso do objeto do artigo, os candidatos eleitos por São Paulo que compóem a bancada evangélica desfrutam de um sólido capital social, seja esse construído como líderes das respectivas congregaçóes ou com o apoio de lideranças religiosas de grande apelo, como cantores e apresentadores. De acordo com a Lei 9.504/97, a propaganda eleitoral no interior dos templos religiosos é expressamente proibida, sendo vedada a veiculação de propaganda de qualquer natureza nesses espaços (BRASIL, 1997). Ainda assim, muitos desses candidatos desfrutam de uma condição de autoridade e de um espaço de campanha privilegiado: as igrejas. Cabenos observar como esse discurso é levado aos meios de comunicação, partindo do pressuposto de que esse deve ser instrumental.

\section{Campanhas de evangélicos nas eleições de 2010, 2014 e 2018}

É a partir do discurso que são estabelecidas disputas e impostas visões de mundo, e é por meio dele que práticas sociais são materializadas. No discurso, segundo Orlandi (2012), é possível observar sujeito, historicidade e ideologia. A noção de ideologia para a autora é ponto forte para análise de discurso. $\mathrm{O}$ argumento é que essa produz um efeito de evidência, que sustenta e naturaliza o "dito" e mobiliza os sentidos já institucionalizados. Portanto, os sentidos não são ocultados quando se trata de ideologia, mas sim do processo de formação delas.

A formação discursiva determina o que deve ser dito a partir do lugar social ocupado por determinado sujeito. Segundo Foucault (2001), trata-se de um conjunto de regras anônimas, históricas, sempre determinadas no tempo e no espaço, que definiram em uma época dada, e para uma área social, econômica, geográfica ou linguística dada, as condições de exercício da função enunciativa.

Assim, buscamos discutir os sentidos mobilizados para a produção do discurso político-eleitoral dos candidatos evangélicos. Primeiramente, analisamos o perfil de cada candidato evangélico eleito ao cargo de Deputado Federal pelo Estado de São 
Paulo nas eleições de 2010, 2014 e 2018. Para tanto, foram identificados os partidos pelos quais esses deputados foram eleitos ou reeleitos e a denominação religiosa de cada um, conforme as tabelas de 1 a 3 . Em seguida, é descrito o perfil político desses eleitos por meio da apresentação da trajetória política e profissional destes, uma vez que muitos desses evangélicos dispóem de cargos importantes dentro de suas denominaçôes, sendo assim bastante influentes nesse meio. $O$ passo seguinte consistiu na seleção dos programas eleitorais desses candidatos exibidos no HGPE durante a campanha dos três pleitos.

A unidade de análise em um primeiro momento é a fala. Considerando o modelo do HGPE brasileiro, tempo e espaço dedicado aos candidatos ao legislativo, buscamos identificar o discurso no texto, uma vez que a fala não é individual, tampouco isolada. O texto, como ressalta Greimas (1975), se forma por uma estrutura que articula elementos e, a partir disso, constitui um sentido coerente. Trata-se de identificar: 1) os antagonismos de valores dentro de um universo semântico que conferem sentido a esse texto; 2) a linha argumentativa do texto, a partir da relaçáo negativa ou positiva atribuída a esses valores. Os mesmos valores identificados em um texto podem estar presentes em diversos outros. Entretanto, o que faz uma narrativa distinta das demais é a forma como esses valores compóem a estrutura discursiva assumida pelo sujeito. Posto isso, faz-se: 3) a identificação dos sujeitos e dos espaços e, por fim, 4) a orientação argumentativa destinada ao receptor. Sendo assim, a análise do discurso dos candidatos evangélicos significa entender os sentidos a partir do sujeito e da sua relação com o contexto sócio-político e histórico, do qual são parte ele mesmo e o receptor.

Importante ressaltar que os "políticos de Deus" citados nas próximas tabelas são aqueles que se declararam evangélicos (em redes sociais, perfil da Câmara dos Deputados, entre outros). 
Tabela 2 - Candidatos Eleitos: 2010

\begin{tabular}{l|l|l|l}
\hline Candidatos Eleitos & Partido & Igreja & Situaçáo \\
\hline Bispo Antônio Bulhóes & PRB & IURD & Reeleito \\
\hline Bruna Furlan & PSDB & Igreja Cristã do Brasil & Eleito \\
\hline Edinho Araújo & PMDB & Igreja Presbiteriana Independente & Eleito \\
\hline Jefferson Campos & PSD & Quadrangular & Reeleito \\
\hline Jorge Tadeu Mudalen & DEM & Internacional da Graça de Deus & Reeleito \\
\hline Marcelo Aguiar & DEM & Igreja Renascer & Eleito \\
\hline Marco Feliciano & PSC & Assembleia de Deus & Eleito \\
\hline Missionário José Olimpo & PP & Mundial do Poder de Deus & Eleito \\
\hline Otoniel Lima & PRB & IURD & Eleito \\
\hline Pastor Paulo Freire & PR & Assembleia de Deus & Eleito \\
\hline Roberto de Lucena & PV & Igreja o Brasil para Cristo & Eleito \\
\hline Vaz de Lima & PSDB & Presbiteriana Independente & Eleito \\
\hline
\end{tabular}

Fonte: Adaptado de DIAP (2018).

Em relação ao perfil dos parlamentares, todos se declaram pertencentes a alguma denominação evangélica. Nota-se que esses políticos estavam espalhados por nove partidos políticos diferentes. Observamos dez diferentes denominaçóes religiosas às quais os candidatos eleitos se declararam como pertencentes, o que demonstra que esses deputados compóem um segmento bastante heterogêneo, uma vez que tais denominaçôes apresentam distintas teologias, o que pode apontar para certa dificuldade de uma bancada evangélica coesa, apesar das bandeiras comuns apresentadas em suas campanhas. Além disso, muitos já haviam ocupado algum cargo político: vereador, prefeito e deputado estadual. A maior parte ocupa papel de destaque em suas igrejas: pastores, bispos, ministros e missionários. Ainda há o caso da deputada Bruna Furlan, que possui um histórico familiar de envolvimento na política. Alguns deles também possuem carreira artística, é o caso dos deputados Marcelo Aguiar e de Marco Feliciano, conhecidos como cantores gospel. Ainda há o caso de Antônio Bulhôes, que era apresentador de TV. 
Tabela 3 - Candidatos Eleitos: 2014

\begin{tabular}{l|l|l|l}
\hline Candidatos Eleitos & Partido & Igreja & Situaçáo \\
\hline Antônio Bulhóes & PRB & Iurd & Reeleito \\
\hline Bruna Furlan & PSDB & Congregaçáo Cristã no Brasil & Reeleita \\
\hline Edinho Araújo & PMDB & Presbiteriana & Reeleito \\
\hline Eduardo Bolsonaro & PSC & Batista & Eleito \\
\hline Jefferson Campos & PSD & Evangelho Quadrangular & Reeleito \\
\hline Fausto Pinato & PP & Congregaçáo Cristã no Brasil & Eleito \\
\hline Jorge Tadeu Mudalen & DEM & Internacional da Graça & Reeleito \\
\hline Missionário José Olimpio & PP & Mundial do Poder de Deus & Reeleito \\
\hline Pastor Gilberto Nascimento & PSC & Assembleia de Deus & Eleito \\
\hline Pastor Marco Feliciano & PSC & Catedral do Avivamento & Reeleito \\
\hline Paulo Freire & PR & Assembleia de Deus & Reeleito \\
\hline Roberto Alves & PRB & Iurd & Eleito \\
\hline Roberto de Lucena & PV & O Brasil para Cristo & Reeleito \\
\hline Vinicius Carvalho & PRB & Iurd & Eleito \\
\hline
\end{tabular}

Fonte: Adaptado de DIAP (2018).

A taxa de reeleição desses candidatos religiosos, na 55a legislatura, é alta. Em outras palavras, quase $70 \%$ dos deputados evangélicos eleitos pelo estado de São Paulo estão no seu segundo mandato. A diversidade de partidos pelos quais esses candidatos são eleitos também continua grande (nove), mas já é possível observar um crescimento de evangélicos ligados ao PRB e PSC. Entre os novos eleitos dessa legislatura, faziam parte: Eduardo Bolsonaro, que é escrivão da polícia federal e frequentador da Igreja Batista; e Gilberto Nascimento, advogado, delegado e pastor evangélico.

${ }^{6}$ Ligada à Assembleia de Deus. 
Tabela 4 - Candidatos Eleitos: 2018

\begin{tabular}{l|l|l|l}
\hline Candidatos Eleitos & Partido & Igreja & Situaçáo \\
\hline Bruna Furlan & PSDB & Congregação Cristã no Brasil & Reeleita \\
\hline Cezinha de Madureira & PSD & Assembleia de Deus & Eleito \\
\hline David Soares & DEM & Internacional da Graça de Deus & Eleito \\
\hline Eduardo Bolsonaro & PSL & Batista & Reeleito \\
\hline Fausto Pinato & PP & Congregação Cristã no Brasil & Reeleito \\
\hline Gilberto Nascimento & PSC & Assembleia de Deus & Reeleito \\
\hline Jefferson Campos & PSD & Evangelho Quadrangular & Reeleito \\
\hline Joice Hasselmann & PSL & Batista & Eleita \\
\hline Marcos Pereira & PRB & IURD & Eleito \\
\hline Maria Rosas & PRB & IURD & Eleito \\
\hline Milton Vieira & PRB & IURD & Eleito \\
\hline Marco Feliciano & PODE & Catedral do Avivamento & Reeleito \\
\hline Paulo Freire & PR & Assembleia de Deus & Reeleito \\
\hline Kátia Sastre & PR & Assembleia de Deus & Eleita \\
\hline Roberto Alves & PRB & IURD & Reeleito \\
\hline Roberto de Lucena & PODE & O Brasil para Cristo & Reeleito \\
\hline Vinicius Carvalho & PRB & IURD & Reeleito \\
\hline Fonte: Adapa &
\end{tabular}

Fonte: Adaptado de DIAP (2018).

$\mathrm{Na} 56^{\mathrm{a}}$ Legislatura nota-se crescimento da bancada evangélica eleita por São Paulo. Do ponto de vista partidário, embora os políticos religiosos ainda estejam distribuídos por diversas agremiações, destaca-se o desempenho do PRB. Entre esses políticos, dois estreantes possuem papel de destaque na IURD: Marcos Pereira, como bispo licenciado, e Milton Vieira, como pastor. Outro destaque é a Deputada e jornalista Joice Hasselmann, eleita pelo PSL com grande expressão de votos; e eleita pela primeira vez a policial Katia Sastre, que ganhou notoriedade midiática após reagir a um assalto na porta de uma escola infantil, em Osasco. Com relação às denominaçôes religiosas desses políticos, se a Igreja Assembleia de Deus é a que possui mais representantes políticos no Legislativo Federal em geral (CASSOTTA, 2019), com relação ao estado de São Paulo, é a IURD que tem se destacado (quase $30 \%$ dos deputados religiosos eleitos são ligados a essa igreja).

Quanto ao espectro ideológico, nas três legislaturas, é visível que esses políticos religiosos estão mais concentrados em partidos identificados à centro-direita 
ou direita 7 . Ou seja, é possível identificar um campo de diálogo pelo qual esses candidatos são eleitos.

Os políticos de Deus podem ser identificados primeiro pelo título que antecede o seu nome: Pastor, Missionário, Bispo. Essa forma de identificação, que em outros casos é usada para indicar profissão de candidatos, é um primeiro passo para a identificação do sujeito no discurso, que resulta da inscriçãoo do sujeito no simbólico (MAGALHÁES e MARIANI, 2010), o que leva indivíduos à identificação com grupos. Dessa forma, as condições de produção do discurso são a instância e contexto social, histórico e ideológico.

\section{As campanhas dos politicos de Deus: 2010, 2014 e 2018}

O pronunciamento ${ }^{8}$ do Bispo Antônio Bulhôes às vésperas das eleições de 2010 é ponto de partida para a compreensão desse sujeito e as condições de produção do discurso:

Olá amigos, eu sou o Bispo Antônio Bulhões. Estou na igreja desde os meus 11 anos de idade, aos 13 me converti e aos 15 anos já fazia a obra de Deus como pastor. Hoje exerço a função legislativa como Deputado Federal, e eu gostaria agora às vésperas da eleição de Outubro, compartilhar uma visão espiritual com vocês a respeito da situaçáo política do nosso país [...] Por muito tempo, por muitas geraçóes, os cristãos viam a política como algo mau, algo do diabo, ao perverso. Com o tempo isso foi mudando [...] e eu vivi a geração de cristãos que viam a política como um mal necessário. Hoje em dia, estando como Deputado Federal posso afirmar que a política é um instrumento, tanto pode ser usada para o bem, quanto pode ser usada para o mal objetivo. Dependendo de quem o use, a quem está investido o poder do mandato [...] Nós sabemos que é importante o povo de Deus se posicionar com seriedade, e encarar a política e a eleição com seriedade [...].

Há quase dois mil anos aconteceu uma eleição e o senhor Jesus era o personagem dessa eleição, um candidato que tinha tudo para ganhar essa eleição, até porque o seu concorrente tinha tudo para perder essa eleição. Jesus era o messias da vida e o seu concorrente era o messias da morte.

\footnotetext{
${ }^{7}$ Considerando a classificação de Rodrigues (2002).

${ }^{8} \mathrm{O}$ pronunciamento foi postado em um canal do YouTube ligado ao bispo e à sua denominação religiosa. $\mathrm{O}$ vídeo, que possui formato e elementos de campanha eleitoral, tais como o número do candidato e partido, foi editado e exibido no HGPE. Disponível em: https://www.youtube.com/watch?v=rdA6_jKBjJY. Acesso em: 16 mar. 2019.
} 
Mas todos nós sabemos que nessa eleição Jesus perdeu e o seu concorrente ganhou a eleição [...]. O povo elegeu Barrabás.

E a pergunta que eu faço é a seguinte: Por culpa de quem Jesus perdeu? E graças a quem Barrabás venceu a eleição? Certamente foi por causa dos cabos eleitorais. Quem eram os cabos eleitorais do senhor Jesus? Os discípulos que estavam escondidos e amedrontados. Quem eram os cabos eleitorais de Barrabás? Os religiosos da época que estavam entre o povo. Esses religiosos como cabos eleitorais eficazes estiveram entre o povo, incitando o povo a pedir pela soltura de Barrabás, e por isso Barrabás venceu aquela eleição.

Agora estamos em Outubro de 2010, mais uma eleição tendo candidatos que representam esse lado da luz, o lado de Jesus, e candidatos que representam o lado das trevas, o lado de Barrabás. Você minha amiga e meu amigo deverá fazer a sua escolha. Que você vote como um cidadão, porém principalmente e como um cristão. Porque uma coisa é certa: o meu Deus é o seu Deus, a minha fé é a sua fé e o meu espírito é o seu espírito. Logo a minha causa é a sua causa.

Eu conto com todos vocês. Que Deus abençoe a todos. (BULHÓES, 2010).

A fala do Bispo demarca exatamente o lugar de fala do sujeito: mensageiro da palavra de Deus. O discurso de campanha é persuasivo por essência; entretanto, não se pode negar o caráter autoritário e lúdico desse discurso. Lúdico pelo contexto histórico apresentado, pelo qual o Bispo justifica o ativismo político dos cristãos e enfatiza a responsabilidade do candidato e do apoiador. Autoritário pela construção do sujeito, uma vez que é o representante da lei de Deus; e principalmente pela atribuição de culpa: cristãos isentos foram os responsáveis pela morte de Jesus há dois mil anos. Cristãos que hoje não trabalham ativamente como cabos eleitorais de seus representantes são os responsáveis pela morte do que Jesus representou. Essa contradição entre luz e trevas é traduzida na campanha eleitoral por outros candidatos.

Luto pela inclusão social e por leis que defendam os princípios cristãos, e os valores da família. Por isso peço o seu voto. (Pr. Jefferson Campos) ${ }^{9}$.

Para o crescimento do evangelho e em defesa da família, com Serra e Geraldo. Chega de lero-lero, Jorge Tadeu é 2500. (Jorge Tadeu) ${ }^{10}$.

\footnotetext{
${ }^{9}$ Propaganda eleitoral exibida durante o HGPE de 2010.

${ }^{10}$ Propaganda eleitoral exibida durante o HGPE de 2010.
} 
Jorge Tadeu é uma liderança importante para DEM, em São Paulo, e quando se pronuncia em nome da legenda, o faz de forma propositiva, indicando as prioridades dos mandados em relação às políticas públicas. Fala como liderança religiosa na campanha, e como liderança do partido em outras inserçôes. De forma contrária a Marco Feliciano, que é líder religioso ${ }^{11}$, tanto nos programas exibidos pelo HGPE quanto nas inserçóes do partido, o deputado e candidato defende as mesmas pautas, e também o faz na eleição seguinte, em outro partido.

Enfrentei uma grande batalha. As suas oraçóes me sustentaram. A luta pela família continua. Peço o seu voto. Pastor Marco Feliciano 2010. (Marco Feliciano) $^{12}$.

Olá, sou o Pastor Marco Feliciano. Hoje em dia é preciso ter coragem em assumir certas posiçóes perante a sociedade. Vivemos tempo onde a família está dividida e sem referências, e isso vem prejudicando a formação dos jovens do amanhã. No PSC, priorizamos a base fundamental da sociedade, que é a família. Trabalhamos para que a qualidade de vida chegue a todos os brasileiros. Precisamos fortalecer nossos valores dentro do lar, que serão exemplos aos nossos filhos. Venham com a gente construir um Brasil melhor! (Marco Feliciano) ${ }^{13}$.

Como parlamentar estive atuante em diversos hospitais do estado de São Paulo, através de emendas para a saúde buscando melhorar a estrutura e o atendimento para a população. Esse trabalho vai continuar. Não se esqueça, para Deputado Federal, 2512, é o poder de filho para São Paulo.

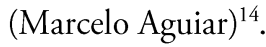

Olá, estado de São Paulo, aquele abraço do apóstolo Valdemiro Santiago. Lhes saldo e conto com você para elegermos novamente o deputado José Olímpio.

Missionário José Olímpio, deputado federal, 1155. (Missionário José Olímpio $^{15}$.

\footnotetext{
${ }^{11}$ Atualmente Marco Feliciano é filiado ao PODEMOS, mas exerceu mandato anterior pelo PSC.

${ }_{12}$ Propaganda eleitoral exibida durante o HGPE de 2014.

${ }^{13}$ Propaganda eleitoral exibida durante o HGPE de 2014.

${ }^{14}$ Propaganda eleitoral exibida durante o HGPE de 2014.

${ }^{15}$ Propaganda eleitoral exibida durante o HGPE de 2014.
} 
Ainda relacionado à autoridade exercida pelas lideranças religiosas, que muitas vezes fazem do púlpito o palanque, a relação entre essas lideranças e os candidatos a outros cargos que se alinham às pautas são exploradas nos próprios templos, ainda que na TV não o sejam. Como já pontuado, a TV, para alguns candidatos, serve apenas como ponto de apoio. São vários os exemplos de pastores que apoiam publicamente candidatos em suas congregações: a família Valadão, pastores e músicos influentes e donos de canal de TV; Apóstolo Valdemiro e o pastor Silas Malafaia, que são exemplos de cabos eleitorais de candidatos em todas as eleições recentes; e o Pastor Paulo Freire, que, além de cabo, é candidato.

Nas eleiçôes de 2018, o apoio de lideranças religiosas evangélicas ao candidato à Presidência Jair Bolsonaro foi um dos destaques do pleito. Silas Malafaia, Edir Macedo e pastor Everaldo (no segundo turno) são algumas das lideranças religiosas que, em nome de Deus, da fé e do conjunto de valores e princípios que compartilham, e contra a corrupção, apoiaram o candidato do PSC. O mesmo pode ser observado nos candidatos evangélicos ao Legislativo por São Paulo.

Se você é contra a liberação das drogas e quer nossos jovens cheios de vida, você está comigo nesta jornada pelo resgate do Brasil. Sou pastor Marco Feliciano e peço o seu voto para deputado federal no 1920, com Marcio 40, para a defesa da família. (Marco Feliciano) ${ }^{16}$.

Pela uniáo do povo brasileiro em defesa da família e a favor da lava jato, Eduardo Bolsonaro, 1720. (Eduardo Bolsonaro) ${ }^{17}$.

A sua luta é a minha luta, pelo fim da corrupção, Frota Federal, 1777. (Alexandre Frota) ${ }^{18}$.

Pra enfrentar essa cambada é Joyce e Bolsonaro, 1771. (Joice Hasselmann $)^{19}$.

\section{Reconhecimento, identificação e autoridade}

O primeiro dispositivo de interpretação a partir do corpus exemplificado se dá pela distinção do eu: representante evangélico, cristão. $O$ "eu” constrói a sua perspectiva: a defesa de valores comuns a partir de uma narrativa compartilhada. Essa

\footnotetext{
${ }^{16}$ Propaganda eleitoral exibida durante o HGPE de 2018.

17 Propaganda eleitoral exibida durante o HGPE de 2018.

${ }^{18}$ Propaganda eleitoral exibida durante o HGPE de 2018.

${ }^{19}$ Propaganda eleitoral exibida durante o HGPE de 2018.
} 
perspectiva é sustentada pela ideia de autoridade que provém da própria condição de liderança. $\mathrm{O}$ "chamado" pastoral e o chamado político se justificam pela fé cristã e são proféticos. Não é coincidência que os candidatos "oficiais" de determinadas denominações são os próprios líderes, não membros comuns ${ }^{13}$.

A defesa de valores tradicionais se expressa mais nitidamente quando esse grupo político assume a narrativa de dois conceitos: vida e família. Esses são os principais antagonismos na construção da interdiscursividade. Afinal, poderíamos questionar: o que é ser a favor da vida? O sentido mobilizado nesse caso está relacionado à questão do aborto e a toda discussão sobre a descriminalizaçáo do mesmo, uma pauta progressista e liberal.

O antagonismo presente na "defesa da família" é ainda mais claro. Família é sinônimo de tradição: pai, mãe e filhos. Homem e mulher heterossexuais, com funçôes claramente definidas: a liderança e o cuidado; a sala e a cozinha; o público e o privado. Essa pauta está relacionada à ampliação dos direitos civis da comunidade LGBT, tais como casamento e adoção, e a promoção de políticas de educação sexual e contra a homofobia.

O discurso se dá na confluência de uma crise econômica e uma profunda crise de representação, pela criminalização da esquerda e por movimentos sociais em nome do combate à corrupção, na defesa de valores tradicionais. Esses movimentos culminaram, nas eleições de 2018, na reorganização do campo conservador em torno do candidato do PSL, em detrimento de lideranças tradicionais e de grandes partidos; e no aumento expressivo do número de parlamentares do mesmo partido do entấo candidato à presidência, que elegeu a segunda maior bancada da câmara dos deputados federal, passando de 1 a 52 eleitos.

Dessa forma, o dito a partir do lugar social ocupado: defender a vida e a família, não é um discurso construído de forma independente, mas está relacionado à ascensão desse conservadorismo e aos seus opostos: a esquerda, tratada de forma genérica, ampla e mais uma vez criminalizada. Essa "esquerda" é representada por determinados partidos, líderes, veículos de imprensa, intelectuais, artistas, entre outros que, de alguma forma, defendem ou discutem a ampliação de direitos de minorias políticas.

Assumir também a pauta da ética na política está relacionado a esse conjunto de valores. A honestidade cristã também compóe essa contradição antiesquerda, responsável - segundo os sentidos mobilizados - pela onda de corrupção que assolou as instituiçóes, estatais e partidos. Nesse ponto, importante ressaltar o diálogo entre a 
descrença nas instituições e o discurso messiânico, no qual o ator é elemento fundamental.

Dessa forma, os sentidos mobilizados nas campanhas dos candidatos são, em resumo, dois: a oferta eleitoral comum, independentemente de partido pelo qual se candidata e da denominação religiosa, baseada na preservação de valores tradicionais; e inimigo comum a ser combatido, que representa a diluição da família, da moral cristá, e um risco à vida. Esse inimigo é representado pela esquerda, novamente, no sentido amplo do conceito.

Valores unificadores sáo comumente explorados em campanhas eleitorais, como atalhos de informação para o eleitor, principalmente em eleiçôes majoritárias. Para citar alguns casos, o "trabalho" como principal slogan de campanha a prefeito de São Paulo de João Dória em 2016 (ALVES, 2017); os diferentes usos do gênero por mulheres (MARTINS e ALTMANN, 2018). O caso aqui estudado, especificamente, reflete uma sociedade polarizada politicamente, fragmentada no nível simbólico (GIDDENS, 2002) e que descredita a política partidária tradicional.

Nesse ponto, retomamos a questão da autoridade da liderança religiosa em relação à campanha eleitoral. $\mathrm{O}$ fundamento da organização social que confere sentido à ação e explica a persistência dessas relações é a dominação Weber (1994, 1985). Tratamos de um "domínio exercido pelo moderno servidor de Estado" (WEBER, 1994, p. 99) decorrente de um processo burocrático racional legal, tal como o processo eleitoral.

Entretanto, “[...] os meios utilizados para alcançar o poder podem ser muito diversos [...] dinheiro, influência social, poder da palavra, sugestão e engano grosseiro [...]" (WEBER, 1994, p. 693), por meio de uma crença de que o sentido não é necessariamente racional. A influência de líderes evangélicos, tanto como candidatos quanto como apoiadores, pode ser discutida também dessa perspectiva, quando indivíduos se orientam por uma crença que corresponde aos anseios do dominante, no caso, eleitorais. Segundo Weber $(1994,1985)$, a dominação carismática é legitimada pelo reconhecimento de um conjunto de atributos extracotidianos do líder.

Charles Lindholm (1993) diz que o carisma é vivenciado e se organiza em torno de uma figura divina, que representa a santidade, para quem as leis são reveladas. Em última instância, trata-se de um guia de um determinado grupo. Nessa relação, o carisma "[...] só aparece na interação com outras pessoas que não o possuem” (LINDHOLM, 1993, p. 19), o reconhecimento entre liderança e liderado, o envolvimento emocional e a condução messiânica. 


\section{Considerações finais}

Buscamos identificar neste artigo quais os sentidos mobilizados para a produção do discurso político-eleitoral dos candidatos eleitos para o cargo de Deputado Federal pelo Estado de São Paulo nas eleições de 2010, 2014 e 2018 que compóem a bancada evangélica. $\mathrm{O}$ argumento foi que a condição religiosa está expressa nos discursos desses candidatos como forma de reconhecimento, identificação e autoridade, vinculando as suas imagens à representação de valores tradicionais no campo político-legislativo. Nota-se que o HGPE é uma fonte de informação política e eleitoral e um meio de dar visibilidade pública às candidaturas e programas de políticos. A análise das campanhas eleitorais desses candidatos, a partir da Análise do Discurso, confirmou a hipótese inicial de que a condição religiosa está expressa nos discursos desses candidatos, que se colocam como representantes de determinados valores. Demonstramos também que se trata de uma oferta comum de políticas que refletem esses valores. Como foi demonstrado, muitos desses políticos se colocam no papel de "mensageiro de Deus", deixando claro seu papel enquanto defensor "dos princípios cristãos" na arena política.

Apesar de ser equivocado supor que evangélico vota em evangélico, não se pode ignorar que "[...] os líderes religiosos desenvolvem vínculos com os membros da igreja e a influência que exercem não é decorrente apenas desta relação, mas é também reflexo do que sua figura representa: um intermediário de Deus" (CERQUEIRA, 2017, p. 91-92). A fala do Bispo Antônio Bulhôes colocada no artigo é um exemplo claro dessa relação de autoridade pastor-ovelha que se estende ao campo político.

Esse papel como um representante de Deus somado à convocação por parte desses religiosos por uma mobilização do "povo cristão", esteve presente no discurso de quase todos os candidatos por nós estudados. A ascensão desses líderes e dessa oferta discursiva, em detrimento da credibilidade de instituiçóes fundamentais da democracia representativa, tais como partidos políticos, é um exemplo da rotinização do carisma, que perpassa as formas tradicionais de dominação e fortalece o personalismo, que é uma das características fundamentais da política eleitoral no Brasil, essencialmente para campanhas majoritárias, mas, nessa perspectiva, também para as proporcionais.

Em última instância, tratamos de um grupo que ressignificou a luta contra corrupção, historicamente uma pauta de partidos progressistas e de esquerda, e ainda mais: dos meios de comunicação (SCHUDSON, 2010; AZEVEDO, 2018). Essa 
pauta se sobrepóe à ampliação de direitos civis e políticos, e está além da ascensão de um conservadorismo e do realinhamento de alguns setores. Essa interdiscursividade, que é resumida em três argumentos - vida, família, e princípios cristãos - unifica, é instrumental pelo seu contexto, e no debate eleitoral não abre margem de diálogo.

Mércia Alves é Doutora em Ciência Política pela Universidade Federal de São Carlos (UFSCar), bolsista FAPESP. Atualmente é membro dos grupos de pesquisa Comunicação Política, Partidos e Eleições (UFSCar) e do Núcleo de Estudos em Arte, Mídia e Política - NEAMP (PUC-SP). E-mail: mercia_f.alves@hotmail.com.

- Priscilla Leine Cassotta é Doutora em Ciência Politica pela UFSCar. Atualmente é membro do Núcleo de Estudos dos Partidos Político Latino-americano (NEPPLA) da Ufscar e do Núcleo de Estudos Comparados Internacionais (NECI) da USP. E-mail: pri.leine@hotmail.com.

\section{Referências}

ALDÉ, Alessandra. O internauta casual: notas sobre a circulação da opinião política na internet.

Revista USP, n. 90, p. 24-41, jun./ago. 2011.

ALMEIDA, Leonardo. O que saber sobre os evangélicos e a política no Brasil: Partidos,

Representantes e Eleiçóes Presidenciais. Curitiba: Editora Prismas, 2014.

ALVES, Mércia. A imagem dos candidatos à prefeitura de São Paulo na campanha eleitoral de 2016.

Agenda Política, v. 5, n. 2, p. 148-170, 2017.

ALVES, Mércia; LIMA, Bárbara. Campanhas e legislação eleitoral: Análise da "minirreforma" no contexto das eleiçóes municipais brasileiras de 2016. Revista Eletrônica de Ciência Política, v. 9, n.

1, p. 119-140, 2018.

AZEVEDO, Fernando Antônio. PT, eleições e editoriais da grande imprensa (1989-2014). Opinião

Pública, v. 24, n. 2, p. 270-290, maio/ago. 2018.

AZEVEDO, Fernando Antônio. Agendamento da política. In: RUBIM, Antônio Albino C.

Comunicação e política: conceitos e abordagens. São Paulo: Editora Unesp, 2004. p 41-71.

BOBBIO, Norberto. Direita e esquerda: razóes e significados de uma distinção política. São Paulo:

Editora Unesp, 1994. 
BRAGA, Sérgio; CARLOMAGNO, Márcio. Eleiçóes como de costume? Uma análise longitudinal das mudanças provocadas nas campanhas eleitorais brasileiras pelas tecnologias digitais (1998-2016). Revista Brasileira de Ciência Política, n. 26, p. 7-62, maio/ago. 2018.

BRAGA, Isabel; VENTURA, Manoel. Bancada Evangélica anuncia apoia a impeachment de Dilma. $O$ Globo, 06 abr. 2016. Disponível em: <https://oglobo.globo.com/brasil/bancada-evangelica-anunciaapoio-ao-impeachment-de-dilma-19032782>. Acesso em: 04 ago. 2019.

BRASIL. Lei n. 13.165, de 29 de setembro de 2015. Altera as Leis n ${ }^{\circ}$ 9.504, de 30 de setembro de 1997, 9.096, de 19 de setembro de 1995, e 4.737, de 15 de julho de 1965 - Código Eleitoral, para reduzir os custos das campanhas eleitorais, simplificar a administração dos Partidos Políticos e incentivar a participação feminina. Diário Oficial da União, 29 set. 2015.

BRASIL. Lei n. 9504, de 30 de setembro de 1997. Estabelece normas para as eleições. Diário Oficial da União, 1 out. 1997.

BULHÓES, Antonio. Bispo Antonio Bulhóes 1010. [S.1.], 2010. (5 min 25 s). Disponível em: $<$ https://www.youtube.com/watch?v=rdA6_jKBjJY>. Acesso em:16 mar. 2019.

CASSOTTA, Priscilla Leine. Partido Social Cristão: organização e distribuição de poder. 2019. 193 f. Tese (Doutorado em Ciência Política) - Programa de Pós-Graduação em Ciência Política, Universidade Federal de São Carlos, São Paulo, 2019.

CASSOTTA, Priscilla Leine. Uma análise do comportamento dos deputados evangélicos no Legislativo brasileiro. E-legis, v. 9, n. 20, p. 75-101, maio/ago. 2016.

CERQUEIRA, Claudia. Igreja como partido: capacidade de coordenação eleitoral da Igreja Universal do Reino de Deus. 2017. 149 f. Tese (Doutorado em Administração Pública), Fundação Getúlio Vargas, São Paulo, 2017.

CHARAUDEAU, Patrick; MAINGUENEAU, Dominique. Dicionário de análise do discurso. São Paulo: Contexto, 2004.

DEPARTAMENTO INTERSINDICAL DE ASSESSORIA PARLAMENTAR (DIAP). Eleiçóes 2018: bancada evangélica cresce na Câmara e no Senado. Portal Fronteira Final, 17 out. 2018. Disponível em:

<https://www.diap.org.br/index.php/noticias/noticias/28532-eleicoes-2018-bancada-evangelica-crescena-camara-e-no-senado >. Acesso em: $11 \mathrm{dez} .2018$.

FARRELL, David M. Political parties in a changing campaign environment. In: CROTTY, Willian; KATZ, Richard S. Handbbok of party politics. [S.1.]: Sage Publication LTD, 2009.

FOUCAULT, Michel. A ordem do discurso. 7. ed. São Paulo: Loyola, 2001.

GIDDENS, Anthony. Modernidade e identidade. Tradução de Plínio Dentzien. Rio de Janeiro: Jorge Zahar, 2002.

GOMES, Wilson. A política de imagem. Revista Fronteiras, v. 1, n. 1, p. 43-52, 1999.

GONÇALVES, Rafael Bruno. Religião e representação política: a presença evangélica na disputa eleitoral brasileira. Revista Espaço Acadêmico, n. 116, p. 13-20, jan. 2011. 
GREIMAS, Algírdas J. Sobre o sentido: Ensaios semióticos. Rio de Janeiro: Vozes, 1975. v. II. INSTITUTO BRASILEIRO DE GEOGRAFIA E ESTATÍSTICA (IBGE). Censo demográfico 2010. Características gerais da população, religião e pessoas com deficiência. Rio de Janeiro: IBGE, 2010

LACERDA, Fábio. Pentecostalismo, Eleiçôes e Representação Política no Brasil Contemporâneo. 2017. 144 p. Tese (Doutorado em Ciência Política) - Departamento de Ciência Política, Universidade de São Paulo, 2017.

LINDHOLM, Charles. Carisma: Êxtase e Perda de Identidade na Veneração ao Líder. Rio de Janeiro: Jorge Zahar, 1993.

LISI, Marco. O comportamento eleitoral nas democracias contemporâneas: um desalinhamento permanente? Portugal em perspectiva comparada. In: FREIRE, André. Eleiçóes e sistemas eleitorais no século XX português: uma perspectiva histórica. Lisboa: Ediçóes Colibri, 2011.

MACHADO, Maria das Dores. Política e Religião: a participação dos evangélicos nas eleições. Rio de Janeiro: Editora FGV, 2006

MAGALHÃES, Belmira; MARIANI, Bethânia. Processos de subjetivação e identificação: ideologia e inconsciente. Linguagem em (Dis)curso, v. 10, n. 2, p. 391-408, maio/ago, 2010.

MANIN, Bernard. A democracia do público reconsiderada. Novos Estudos Cebrap, n. 97, p. 115$127,2013$.

MANIN, Bernard. As metamorfoses do governo representativo. Revista Brasileira de Ciências Sociais, ano 10, n. 29, p. 5-34, 1995.

MARIANO, Ricardo. Neopentecostais: sociologia do novo pentecostalismo no Brasil. São Paulo: Ediçóes Loyola, 2005.

MARIANO, Ricardo, HOFF, Márcio; DANTAS, Souza de Y. Evangélicos sanguessugas, presidenciáveis e candidatos gaúchos: a disputa pelo voto dos religiosos. Debates do NER, ano 7, n. 10, p. 65-78, 2006.

MARIANO, Ricardo; PIERUCCI, Antônio Flávio. O envolvimento dos Pentecostais na eleição de Collor. Novos Estudos Cebrap, v. 3, n. 34, p. 92-106, nov. 1992.

MARTINS, Joyce Miranda Leão; ALTMANN, Cristina. Os usos do gênero na campanha presidencial de 2014: mulheres na propaganda eleitoral brasileira. Revista Teoria \& Pesquisa, v. 27, n. 1, p. 4870, 2018.

MORAES, Camila. A militante anti-aborto recrutada por Temer para a Secretaria de Mulheres. El País, 02 jun. 2016. Disponível em: <https://brasil.elpais.com/brasil/2016/06/02/politica/1464821271_104776.html>. Acesso em: 04 ago. 2019.

ORLANDI, Eni Pulcinelli. Análise de discurso: princípios e procedimentos. 10. ed. São Paulo: Pontes Editores, 2012.

ORO, Ari Pedro. Algumas interpelações do Pentecostalismo no Brasil. Horizonte, v. 9, n. 22, p. 383$395,2011$. 
ORO, Ari Pedro. Religião e Política no Brasil. In: ORO, Ari Pedro (Org.). Religião e Política no Cone-sul, Argentina, Brasil e Uruguai. São Paulo: Attar Editorial, 2006. p. 75-156.

ORO, Ari Pedro; MARIANO, Ricardo. The reciprocal instrumentalization of religion and politics in Brazil. Annual Review of the Sociology of Religion, v. 2, p. 245-266, 2011.

PANKE, Luciana; MACEDO, Roberto Gondo. HGPE: desafios e perspectivas nos 50 anos do Horário Gratuito de Propaganda Eleitoral no Brasil. Capivari, SP: Editora Nova Consciência, 2013. PIERUCCI, Antônio Flávio; PRANDI, Reginaldo. A Realidade Social das Religióes no Brasil: religião, sociedade e política. São Paulo: Editora Hucitec, 1996.

RODRIGUES, Leôncio M. Partidos Ideologia e Composição Social. Revista Brasileira de Ciências Sociais, v. 17, n. 48, p. 31-47, fev. 2002.

SANTOS, Lívia Reis. Confiança ou cabresto? Consideraçóes sobre o comportamento eleitoral de um grupo evangélico nas eleiçóes municipais de 2012. Revista Intratextos, v. 4, n. 1, p. 73-92, 2013.

SCHUDSON, Michael. Descobrindo a notícia: uma história social dos jornais nos Estados Unidos. Petrópolis, RJ: Vozes, 2010.

SOUZA, André Ricardo de. O desempenho político-eleitoral dos evangélicos de 1986 a 2008 . In: Encontro Nacional do GT História das religióes e das religiosidades, 2., Maringa-PR, 2009.

TADVALD, Marcelo. Eleitos de Deus e pelo povo: os evangélicos e as eleiçóes federais de 2010. Debates do NER, v. 2, n. 18 p. 83-109, 2010.

WEBER, Maria H. Imagem pública. In: RUBIM, Antonio (Ed.). Comunicação e política: conceitos e abordagens. Salvador: Edufba, 2004. p. 259-307.

WEBER, Max. Economia e sociedade: fundamentos de sociologia compreensiva. 3. ed. Brasília: UNB, 1994. v. 1.

WEBER, Max. Ciência e política. São Paulo: Cultrix, 1985.

Texto recebido em 15 de agosto de 2019. Aprovado em 29 de janeiro de 2020. 